\title{
Analisis Mutu Produk Pengolahan Hasil Pertanian: Fruit Strips Frutivez dengan Statistical Process Control
}

\author{
Sasvia Ayu Puzianti ${ }^{1 *}$, Totok Pujianto ${ }^{2 *}$, dan Roni Kastaman ${ }^{2 *}$ \\ ${ }^{1}$ Program Studi Teknologi Industri Pertanian, Fakultas Teknologi Industri Pertanian, \\ Universitas Padjadjaran \\ ${ }^{2}$ Fakultas Teknologi Industri Pertanian, Universitas Padjadjaran \\ Jl. Raya Bandung-Sumedang Km 21 \\ *Alamat korespondensi: totok.pujianto@unpad.ac.id
}

\begin{tabular}{|c|c|}
\hline INFO ARTIKEL & ABSTRACT/ABSTRAK \\
\hline Diterima: $\quad 14-09-2021$ & \\
\hline Direvisi: $\quad 18-11-2021$ & Quality Analysis of Agricultural Processing I \\
\hline Dipublikasi:23-01-2022 & Frutivez with Statistical Process Control \\
\hline
\end{tabular}

Keywords:

Fruit strips, Quality control management, SPC

Kata Kunci:

Fruit strips, Manajemen engendalian mutu, SPC
Quality control is a basic thing that needs to be applied by an organization, agency, or company to produce services or products that can meet consumer needs. Defects that may occur in a production can cause gradual losses for the company. Fruit strips Frutivez as a whole meet the standards of fruit strips that consumers want, but often the products received by consumers are damaged. The purpose of this study was to analyze the quality of Frutivez products based on fruit strips standarded by consument using statistical process control. Defect is caused by labour factors (employees and couriers), employee boredom, and equipment that is no longer suitable for use. The solutions provided are improving packaging methods, hold gathering events, and equipment replacement and maintenance. The final percentage rate of acceptance of the solution by the company is $78 \%$, which means it is very likely that the given solution can be implemented.

Pengendalian mutu merupakan hal dasar yang perlu diterapkan oleh sebuah organisasi, instansi, maupun perusahaan untuk mengahasilkan jasa ataupun produk yang dapat memenuhi kebutuhan konsumen. Kecacatan yang mungkin terjadi dalam suatu produksi dapat menyebabkan kerugian secara bertahap bagi perusahaan. Fruit strips Frutivez secara keseluruhan dapat memenuhi standar fruit strips yang diminati oleh konsumen, namun sering produk yang diterima oleh konsumen dalam keadaan yang patah. Tujuan penelitian ini adalah untuk menganalisis mutu produk Frutivez berdasarkan standar fruit strips yang diminati oleh konsumen menggunakan analisis statistical process control. Kecacatan disebabkan oleh karena faktor tenaga kerja (karyawan dan kurir), kejenuhan karyawan, dan peralatan yang sudah usang. Solusi yang diberikan adalah perbaikan metode pengemasan, mengadakan rekreasi bersama, serta penggantian dan pemeliharaan peralatan. Tingkat presentase akhir penerimaan solusi tersebut oleh pihak perusahaan sebesar $78 \%$ yang berarti kemungkinan besar solusi yang diberikan dapat diimplementasikan. 


\section{PENDAHULUAN}

Pentingnya menjaga kesehatan dalam berkegiatan merupakan hal yang perlu diperhatikan mengingat manusia merupakan makhluk hidup yang perlu melakukan aktivitas. Makanan yang dikonsumsi perlu diperhatikan nutrisi dan juga gizinya guna menjaga imunitas tubuh. Konsumsi vitamin dan serat merupakan hal yang masih sering tidak diindahkan dalam konsumsi pangan seharihari. Vitamin dan serat ini dapat diperoleh dengan mengonsumsi sayur dan buah. Anak-anak lebih cenderung malas mengonsumsi sayur dan buah karena belum paham manfaatnya sehingga mereka lebih cenderung memilih untuk mengonsumsi camilan yang lebih menarik dari segi visual maupun rasa bagi mereka.

Sayuran dan buah-buahan memiliki manfaat bagi tubuh antara lain sebagai sumber vitamin dan serat, dan yang penting adalah menopang kehidupan manusia untuk menjaga agar tubuh tetap sehat (Hamidah, 2015). Tubuh manusia dapat memproduksi vitamin secara alami namun jumlah tersebut belum mampu memenuhi jumlah vitamin yang diperlukan oleh tubuh. Kebutuhan konsumsi vitamin harian yang diperlukan oleh tubuh relatif kecil, namun konsumsi vitamin terutama dari sayur dan buah baik untuk menjaga stamina tubuh.

Tanah subur seperti di Indonesia yang beriklim tropis memungkinkan untuk ditumbuhi beraneka ragam tanaman baik sayur maupun buah. Buah-buahan yang dapat ditanam di Indonesia ada 25 macam seperti pepaya, nanas, alpukat, mangga, pisang, dan sebagainya. Produksi buah-buahan di Indonesia untuk setiap jenisnya pun terus meningkat dari tahun ke tahun (Badan Pusat Statistik, 2018). Pengembangan produk olahan buah-buahan berpotensi untuk dikembangkan guna meningkatkan nilai tambah dan masa simpan dari buah-buahan. Produk olahan ini dapat menjadi ciri khas bagi beberapa daerah penghasil buah tertentu dan dapat menjadi daya tarik tersendiri bagi wisatawan yang berkunjung ke Indonesia.

Fruit strips merupakan salah satu produk turunan yang merupakan lembaran tipis dengan ketebalan sekitar 2-3 mm terbuat dari pure buah yang dikeringkan hingga kadar airnya minim sekitar 10$15 \%$ dan berpotensi untuk dikembangkan di Indonesia. Berbagai jenis buah yang dapat dijadikan bahan baku fruit strips beraneka ragam namun cenderung pada buah-buah yang memiliki kadar air cukup tinggi seperti buah nenas, mangga, pepaya, apel, pisang, nangka, jambu biji, sirsak dan sebagainya (Enie \& Nami, 1992; Yilmaz, Yuksekkaya, Vardin, \& Karaaslan, 2017). Rasa dari setiap buah yang berbeda berdampak pula pada rasa fruit strips yang dihasilkan. Pemanis tambahan tidak diperlukan dalam pembuatan fruit strips karena rasa manis tersebut berasal dari rasa manis buah yang digunakan.

Setiap konsumen memiliki kebutuhan dan keinginan yang berbeda-beda sehingga perusahaan berusaha untuk memenuhi ragam keinginan konsumen tersebut. Jika kualitas produk yang dihasilkan perusahaan dapat memenuhi permintaan konsumen, maka keragaman produk yang dihasilkan tidak terlalu menjadi masalah bagi konsumen. Kontrol kualitas diperlukan tidak hanya untuk memenuhi kepuasan pelanggan, tetapi juga untuk memungkinkan perusahaan tetap kompetitif dalam persaingan bisnis (Elan \& Kusmindah, 2016). Jika kualitas produk yang ditawarkan memenuhi standar, maka konsumen akan merasa puas dengan barang atau jasa yang dijual oleh perusahaan. Standarstandar ini dapat dikendalikan oleh kontrol kualitas yang diterapkan oleh perusahaan. Pengendalian kualitas merupakan salah satu hal yang harus dilakukan perusahaan untuk mengurangi resiko produk cacat (Amanah, 2010).

Pengendalian mutu atau biasa dikenal dengan istilah quality control (QC) adalah tindakan pengendalian yang dilakukan oleh sebuah perusahaan untuk mengontrol kualitas produk dan jasa yang diproduksinya. Upaya penerapan pengendalian mutu ini berdampak pada pengeluaran biaya oleh perusahaan, namun manfaat pengendalian mutu yang dilakukan perusahaan sebanding dengan biaya awal yang dikeluarkan. Perusahaan yang menerapkan pengendalian mutu memiliki kualitas produk yang baik dan sedikit produk yang cacat, yang memudahkan perusahaan untuk memasarkan produknya (Elmas, 2017).

Pengendalian mutu perlu diterapkan oleh semua unit sistem organisasi atau perusahaan yang tujuannya memberikan pelayanan atau produk yang dapat memuaskan konsumen (Winarsih, 2017). Tujuan dari pengendalian kualitas itu sendiri adalah untuk meyakinkan konsumen bahwa produk yang diproduksi oleh perusahaan berkualitas tinggi dan dapat memenuhi kebutuhan mereka (Ramadhany \& Supriono, 2015). Pengendalian mutu berguna dalam mengurangi jumlah produk cacat akibat proses produksi (Ratnadi \& Suprianto, 2016). Cacat yang lebih sedikit dapat menurunkan biaya perbaikan dan meningkatkan laba perusahaan. Pengendalian mutu 
sangat penting untuk menjaga reputasi perusahaan karena kepercayaan konsumen terhadap suatu perusahaan dapat dilihat dari kualitas produk yang dihasilkannya (Nastiti, 2014).

PT. Saudagar Buah Indonesia (PT. SABUSI) adalah perusahaan yang mengelola produk turunan pangan berupa fruit strips. Fruit strips yang diproduksi oleh perusahaan memiliki merek dagang Frutivez. Fruit strips Frutivez dibuat dalam tiga varian yang terbuat dari olahan pure mangga, pisang, dan pinepaya (campuran dari pepaya dan nanas). Pure buah ini dikeringkan menggunakan mesin yang sesuai yang memungkinkan bahan dikeringkan sampai kadar air tertentu, yaitu mesin dehidrator. Proses produksi yang dilakukan oleh perusahaan mayoritas dilakukan secara manual, mulai dari mengiris buah, penghalusan dengan blender, meratakannya di atas nampan, hingga proses pemotongan lembaran dan juga pengemasan.

Pengendalian mutu yang diterapkan oleh perusahaan dalam produksi fruit strips masih terbatas dan metode pengendalian mutu belum diterapkan. Selama ini pengendalian kualitas yang dilakukan perusahaan masih sebatas pada prosedural menjaga kebersihan dalam proses produksi, seperti penggunaan sarung tangan, celemek, topi dan masker. Hal ini menghasilkan ketidakseragaman yang cukup besar dalam segi ukuran, ketebalan, kerataan, dan lainnya dari produk. Contoh penyebab perbedaan ukuran antar produk adalah saat mencetak produk dilakukan secara manual menggunakan kertas cetakan $5 \times 7 \mathrm{~cm}$ yang jumlahnya terbatas. Oleh karena itu, perusahaan perlu menerapkan kontrol kualitas dalam proses produksi. Salah satu metode yang dapat digunakan untuk pengendalian kualitas adalah metode Statistical Process Control (SPC).

Menjaga mutu produk sesuai standar yang telah ditetapkan merupakan kegiatan dalam pengendalian kualitas. Penerapan pengendalian mutu efektif yang dilakukan oleh perusahaan memungkinkan untuk menghasilkan produk dengan standar kualitas yang memenuhi kebutuhan konsumen (Rusydah \& Utomo, 2019). Upaya untuk mengurangi risiko kerusakan harus dikendalikan melalui penerapan pengendalian mutu agar dapat meminimalkan kemungkinan kerugian yang besar bagi perusahaan.

SPC adalah alat yang dapat digunakan untuk mengontrol kinerja suatu proses menggunakan metode statistik. Analisis pengendalian mutu ini dilanjutkan dengan analisis faktor yang memengaruhi produksi, penyebab masalah, dan menentukan apakah kualitas sesuai dengan standar yang telah ditetapkan (Sari \& Purnawati, 2018). Terdapat beberapa instrumen yang biasa digunakan untuk mengukur pengendalian mutu dalam metode SPC, yang merupakan bagian dari seven tools. Alatalat ini termasuk control chart, histogram, diagram Pareto), dan fishbone diagram (Heizer \& Render, 2011).

Seperti disebutkan sebelumnya, belum ada metode pengendalian mutu tertentu yang diterapkan pada produk Fruitivez yang diproduksi oleh PT. SABUSI. Oleh karena itu, penelitian ini bertujuan untuk menganalisis pendekatan penerapan metode pengendalian kualitas produk Frutivez menggunakan metode SPC dengan fokus pada pengendalian kualitas produk. Berdasarkan survei pendahuluan yang dibagikan kepada 100 responden untuk mendapatkan kriteria standar fruit strips, konsumen tidak hanya memperhatikan bentuk fruit strips, tetapi juga dari segi rasa, ukuran, ketebalan, tekstur permukaan, dan bentuk sehingga penelitian ini akan fokus pada variabel-variabel tersebut.

\section{BAHAN DAN METODE}

Penelitian ini dilakukan di PT. SABUSI yang berlokasi di Jl. GKPN Perumahan Grand Cipacing No. 42, Jatinangor, Jawa Barat. Penelitian ini dilakukan pada bulan Mei hingga Agustus 2021. Fokus dari penelitian ini adalah pada kesesuaian mutu produk fruit strips mengacu pada standar yang ditetapkan oleh konsumen, kemudian diolah menggunakan control chart dan fishbone diagram. Variabel yang diukur lebih lanjut adalah variabel rasa, ukuran, ketebalan, tekstur permukaan, dan juga bentuk produk yang diambil datanya menggunakan teknik proportionate stratified random sampling. Berikut rumus perhitungan yang digunakan dalam perhitungan control chart dalam penelitian ini (Oakland, 2008):

\section{- X-bar- $R$-Chart}

$\dot{\mathrm{X}}=\left(\sum \mathrm{Xi}\right) / \mathrm{n}$

Keterangan:

$\dot{\mathrm{X}}=\mathrm{X}$ bar

$\mathrm{Xi}=$ jumlah produk yang tidak sesuai dalam populasi

$\mathrm{n} \quad=$ jumlah populasi 
$\mathrm{XDbl}$ bar $=\left(\sum \mathrm{Xi}\right) / \mathrm{n}$

Keterangan:

$\mathrm{Xi}=$ jumlah produk yang tidak sesuai dalam populasi

$\mathrm{n} \quad=$ jumlah populasi

$\mathrm{R}=\mathrm{Xi}$ maks $-\mathrm{Xi}$ min

Keterangan:

$\mathrm{Xi}$ maks = Nilai $\mathrm{X}$ maksimal dalam 1 hari

$\mathrm{Xi} \min =$ Nilai $\mathrm{X}$ minimal dalam 1 hari

$\hat{\mathrm{R}}=\left(\sum \mathrm{R}\right) / \mathrm{N}$

Keterangan:

$\hat{\mathrm{R}}=\mathrm{R}$ bar

$\Sigma \mathrm{R}=$ Total nilai range

$\mathrm{N}=$ Populasi

CL X-bar $=\ddot{\mathrm{X}}=\left(\sum \dot{\mathrm{X}}\right) / \mathrm{N}$

CL R-Chart $=\hat{\mathrm{R}}$

UCL X-bar $=\ddot{\mathrm{X}}+(\mathrm{A} 2 * \hat{\mathrm{R}})$

UCL R-Chart $=\mathrm{D} 4{ }^{*} \hat{\mathrm{R}}$

LCL X-bar $=\ddot{X}-(A 2 * \hat{R})$

LCL R-Chart $=\mathrm{D} 3{ }^{*} \mathrm{R}$

Keterangan:

Nilai konstanta A2, D2, D3, dan D4 merupakan nilai yang diambil dari Tabel konstanta untuk control chart

- $p$-Chart

$\mathrm{P}=\mathrm{np} / \mathrm{n}$

Keterangan:

$\mathrm{P} \quad=$ nilai rata-rata produk tidak sesuai

$\mathrm{np}=$ jumlah produk yang tidak sesuai

$\mathrm{n} \quad$ = jumlah sampel

$\mathrm{UCL}=\mathrm{P}+3 \sqrt{ }((\mathrm{P}(1-\mathrm{P})) / \mathrm{n})$

$\mathrm{LCL}=\mathrm{P}-3 \sqrt{ }((\mathrm{P}(1-\mathrm{P})) / \mathrm{n})$

$\mathrm{CL}=\mathrm{P}$

Keterangan:

UCL = Nilai batas kendali atas

LCL = Nilai batas kendali bawah

$\mathrm{P}=$ nilai rata-rata produk tidak sesuai

Jenis peta kendali untuk perhitungan variabel penelitian ini (variabel ukuran dan ketebalan) adalah jenis $x$-bar - $R$-Chart, sementara untuk penilaian atribut penelitian (atribut rasa, bentuk, dan tekstur permukaan) adalah jenis $p$-Chart. Pengukuran variabel dilakukan oleh peneliti, sementara untuk penilaian atribut dinilai oleh dua orang tenaga ahli serta peneliti. Hasil pengukuran diverifikasi terhadap standar produk yang diharapkan konsumen berdasarkan data yang diperoleh melalui survei. Jika nilai hitung melebihi garis kendali bawah (LCL), sampel dinyatakan masuk ke dalam standar, sedangkan jika nilai hitung melebihi garis kendali atas (UCL), sampel dinyatakan tidak memenuhi standar. Sampel yang ditetapkan dalam batas standar adalah sampel yang dihitung antara batas bawah dan batas kendali atas.

Ketidaksesuaian sampel terhadap standar kemudian dicari faktor penyebabnya melalui wawancara dengan stakeholder yang memiliki kontak langsung dengan proses produksi. Hasil wawancara ini dianalisis lebih lanjut untuk faktorfaktor yang berkontribusi terhadap kecacatan menggunakan fishbone diagram. Perbaikan diperlukan untuk mengurangi jumlah produk cacat yang mungkin dihasilkan dalam produksi fruit strips Frutivez.

Bahan baku pembuatan fruit strips Frutivez untuk satu kali produksi adalah pure mangga sebanyak $2700 \mathrm{ml}$, pure pinepaya $3150 \mathrm{ml}$ dan pure pisang $2700 \mathrm{ml}$. Pengukuran sampel dalam penelitian ini bersifat dapat merusak produk karena salah satu pengujiannya memerlukan uji organoleptik, sehingga jumlah sampel yang digunakan hanya sedikit dan termasuk ke dalam destructive measurement (Mast \& Trip, 2005). Maka berdasarkan kesepakatan, sampel yang digunakan dalam penelitian ini diambil sebanyak 5 lembar untuk setiap varian dari setiap produksi yang diamati selama 30 hari. Peralatan yang digunakan untuk memproduksi fruit strips antara lain adalah mesin dehidrator, tray, dan alat pemotong. Sementara itu, peralatan yang digunakan untuk pengukuran ini adalah kertas tracing dari setiap bentuk sampel serta digital vernier caliper.

\section{HASIL DAN PEMBAHASAN}

\section{Gambaran Umum}

Frutivez adalah merek untuk fruit strips yang diproduksi oleh PT. SABUSI sejak tahun 2019. Hingga tahun 2021 varian Frutivez ada tiga yaitu mangga, pisang, dan pinepaya (campuran pepaya dan nanas). Produk Frutivez dijual secara online, yang dapat ditemukan di e-commerce seperti Shopee, 
Tokopedia dan Blibli, serta toko offline, dimana produk ini dapat dibeli di beberapa toko mitra di wilayah Bandung dan Jabodetabek.

\section{Standar Fruit Strips yang Diminati Konsumen}

Standar fruit strips ditetapkan dari penyebaran kuesioner pada 100 orang responden yang terdiri dari 60 orang perempuan dan 40 orang laki-laki yang pernah mengonsumsi fruit strips. Fruit strips yang digemari adalah fruit strips yang memiliki rasa manis asam, berkisar antara $30-40 \mathrm{~cm}^{2}$, dengan ketebalan 0,05 mm, berbentuk persegi panjang utuh, dan memiliki tekstur permukaan yang agak bertekstur. Sementara itu, responden tidak terlalu memperhatikan warna dari fruit strips karena menurut responden fruit strips dengan warna gelap maupun terang tidak menjadi masalah.

\section{Analisis Fruit Strips Frutivez}

Berdasarkan pengamatan terhadap sampel yang dilakukan selama 30 hari produksi, didapatkan hasil bahwa fruit strips Frutivez secara keseluruhan mendekati standar minat konsumen namun terdapat data penyimpangan pada bentuk produk. Penyimpangan bentuk produk ini terjadi pada hari ke-4 untuk varian mangga dan pinepaya dengan tanggal produksi 19 Juli 2021 yang bertepatan satu hari sebelum Hari Raya Idul Adha serta pada hari ke14 untuk varian pisang dengan tanggal produksi 29 Juli 2021 dimana salah seorang karyawan divisi produksi izin tidak masuk kerja. Penyimpangan ini adalah penyimpangan yang melewati batas kendali atas (UCL) dimana untuk bentuk varian mangga adalah 0,87 sementara datanya adalah 0,93 , untuk bentuk varian pinepaya UCL-nya adalah 0,84 sementara datanya adalah 0,87 , dan bentuk varian pisang memiliki UCL sebesar 0,92 sedangkan datanya sebesar 0,93 .

Data untuk variabel dan atribut selain bentuk mengalami naik (run up) dan turun (run down) yang juga tidak beraturan, namun data-data tersebut masih berada dalam batas garis kendali atas dan bawah. Perbedaan jarak yang besar antara garis kendali atas dan garis kendali bawah ini sebaiknya diminimalisir untuk menandakan bahwa produk yang dihasilkan seragam. Berikut disajikan grafik data sampel fruit strips Frutivez untuk atribut rasa, bentuk, dan tekstur permukaan dalam Gambar 1. Sementara itu, untuk untuk variabel ukuran dan ketebalan disajikan dalam Gambar 2.

\section{Analisis Sebab-Akibat (Fishbone Diagram)}

Diagram sebab-akibat digunakan untuk mengidentifikasi penyebab atau masalah yang menyebabkan gejala atau efek. Gejala yang ditemukan dalam penelitian ini adalah kasus dimana terjadi penyimpangan atau cacat pada bentuk akhir produk yang diterima oleh konsumen. Analisis dilakukan dengan mewawancarai stakeholder yang terkait erat dengan produksi. Hasil wawancara menunjukkan bahwa bentuk akhir produk masih menjadi masalah umum pada produk Frutivez di setiap varian. Hal ini disebabkan oleh beberapa faktor utama: tenaga kerja, metode yang digunakan, bahan baku, serta alat dan mesin yang digunakan dalam produksi.

Dikarenakan metode manual masih digunakan dalam produksi fruit strips Frutivez, tenaga kerja memiliki dampak besar pada bentuk akhir produk. Kecacatan bentuk yang sering terjadi selama produksi disebabkan oleh faktor internal dan eksternal. Sebagai perusahaan luar yang menerima banyak pesanan, jasa kurir merupakan salah satu faktor penyebab terjadinya cacat bentuk fruit strips (cacat patah, remuk) yang diterima konsumen. Pada tanggal kecacatan bentuk yang melebihi standar pun ditemukan adanya pekerja yang absen pada hari tersebut. Pekerja sering tidak memakai headcap selama produksi, ini mungkin salah satu faktor yang dapat mempengaruhi produk akhir fruit strips, tetapi faktor-faktor ini secara tidak langsung mempengaruhi bentuk fruit strips.

Selain tenaga kerja, faktor lain yang mempengaruhi adalah metode, dimana ada masalah dengan metodepengiriman dan juga metode pemotongan yang masih manual. Produk yang dikirim oleh perusahaan menggunakan dus, bubble wrap, dan penanda pecah belah (fragile), tetapi hal tersebut belum cukup untuk melindungi produk di dalamnya dari benturan dan tekanan tumpukan paket lain. Dus yang disediakan oleh perusahaan terbuat dari bahan yang tipis, sehingga mudah penyok. Peralatan tray milik perusahaan sudah tidak rata sehingga menyulitkan pekerja saat melakukan pemotongan. 


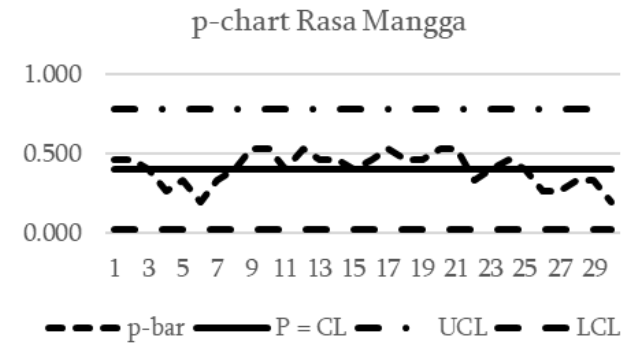

(a)

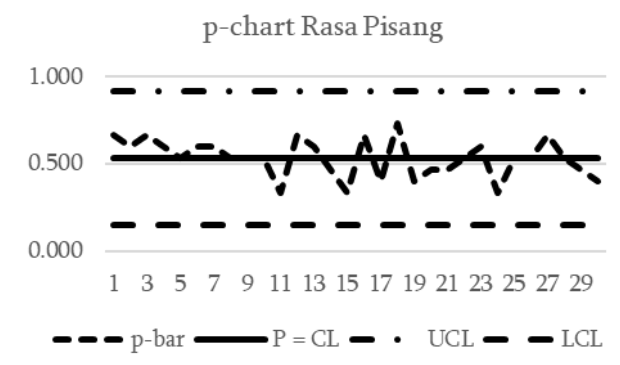

(c)

p-chart Bentuk Pinepaya

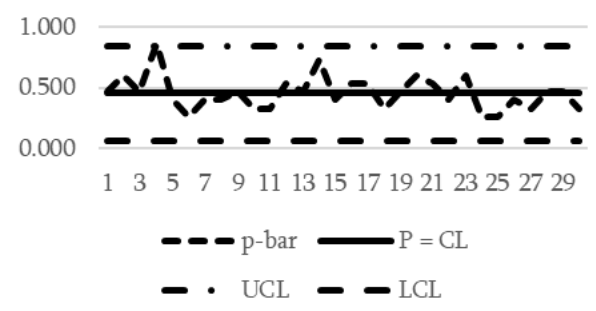

(e)

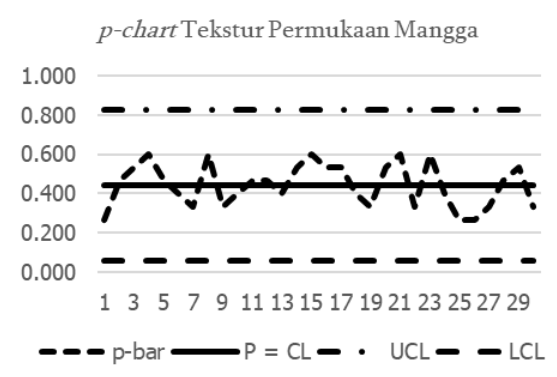

(g)

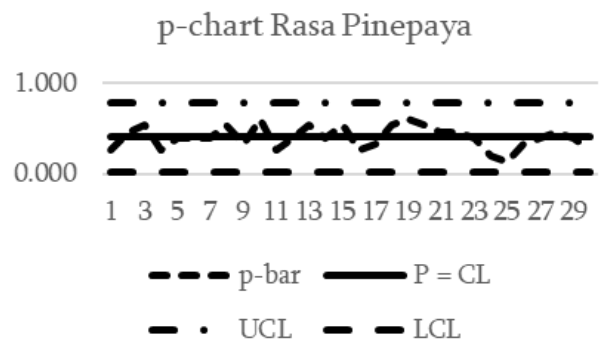

(b)

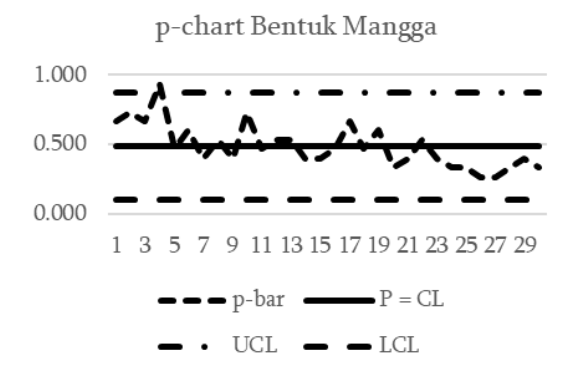

(d)

p-chart Bentuk Pisang

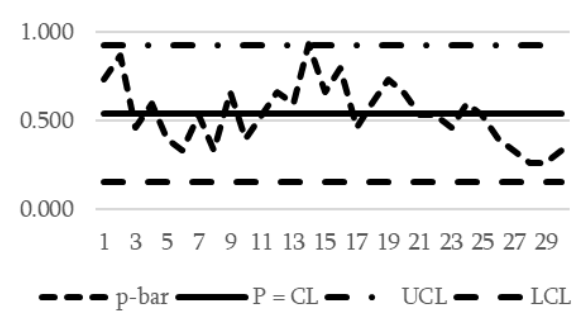

(f)

p-chart Tekstur Permukaan Pinepaya

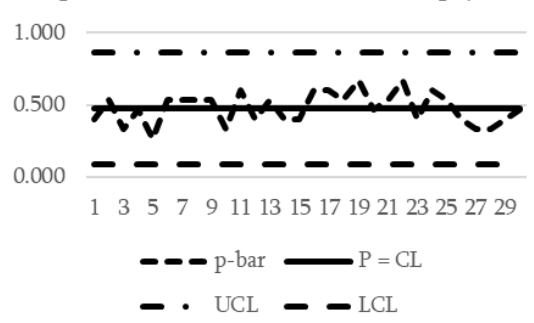

(h)

p-chart Tekstur Permukaan Pisang

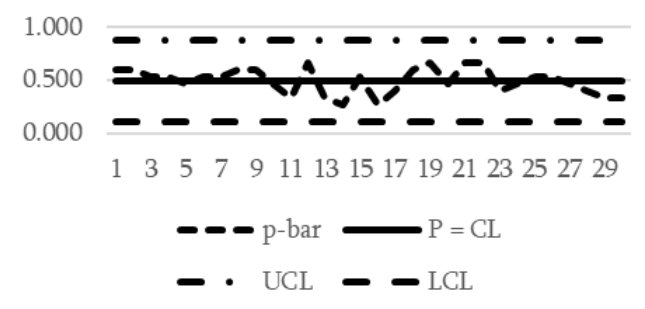

(i)

Gambar 1. Grafik p-Chart fruit strips Frutivez. (a) Rasa varian mangga. (b) Rasa varian pinepaya. (c) Rasa varian pisang (d) Bentuk varian mangga. (e) Bentuk varian pinepaya. (f) Bentuk varian pisang. (g) Tekstur varian mangga. (h) Tekstur varian pinepaya. (i) Tekstur varian pisang 


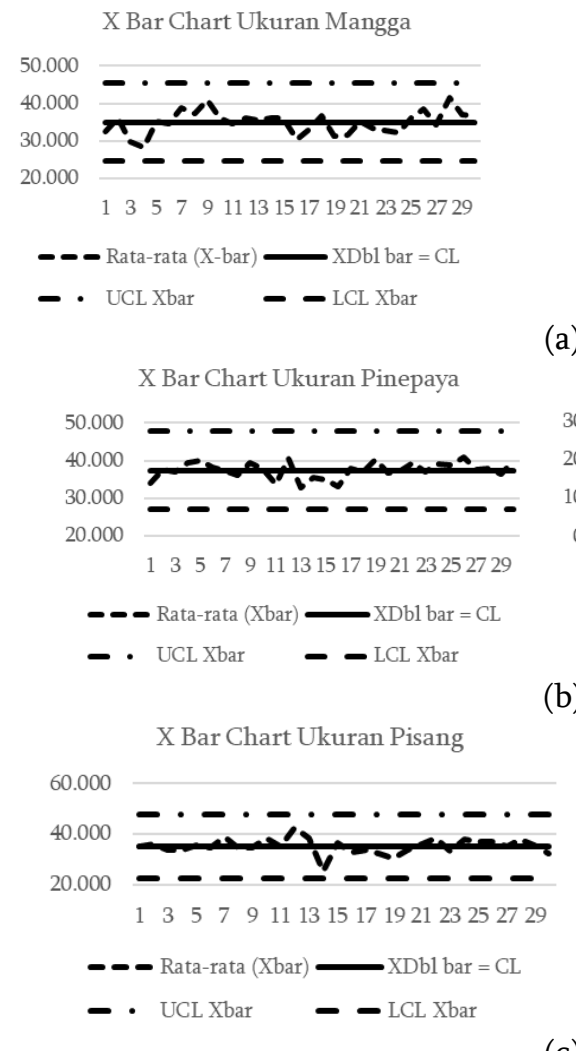

(c)

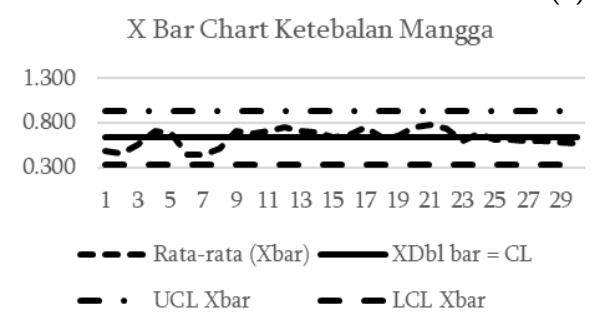

(d)

(b)

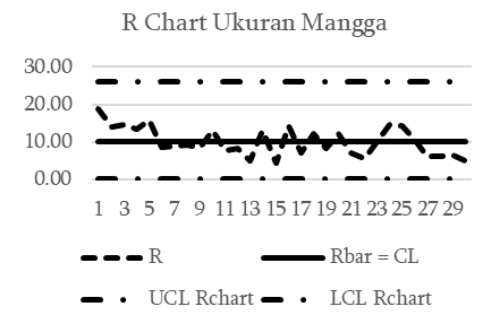

R Chart Ukuran Pinepaya
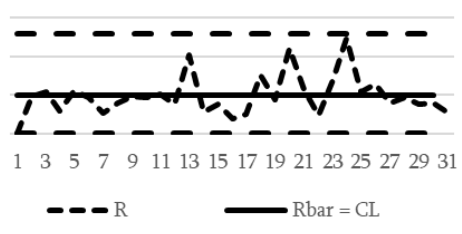

- - UCL Rchart - - LCL Rchart
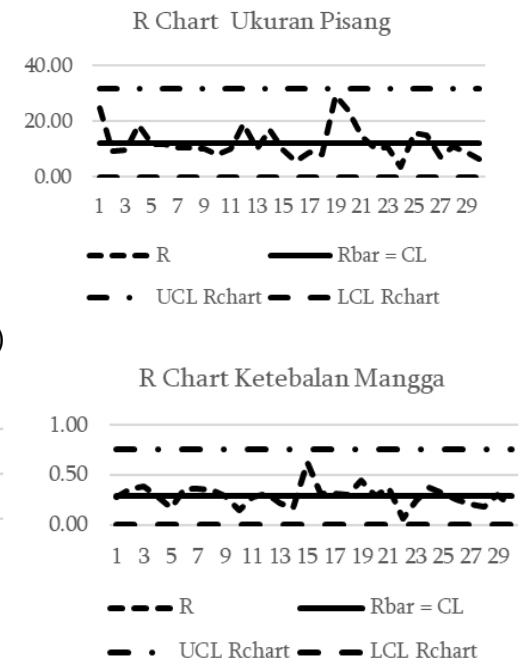

X Bar Chart Ketebalan Pinepaya

R Chart Ketebalan Pinepaya

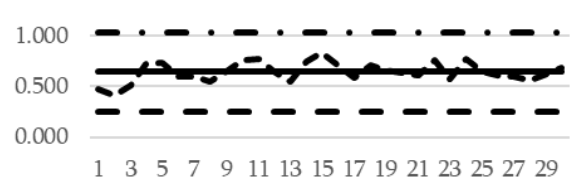

$1.00-\cdots-\cdot \cdots \cdot \cdot \cdots \cdot$

0.50

0.00 - ㅡ-1 - - - - -

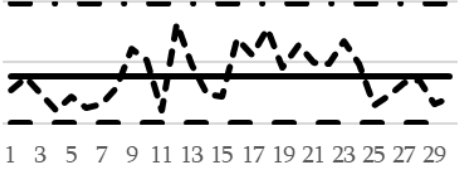

- - Rata-rata $(\mathrm{Xbar}) \longrightarrow$ XDbl bar $=\mathrm{CI}$

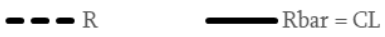

- • UCL Rchart - - LCL Rchart

(e)

X Bar Chart Ketebalan Pisang

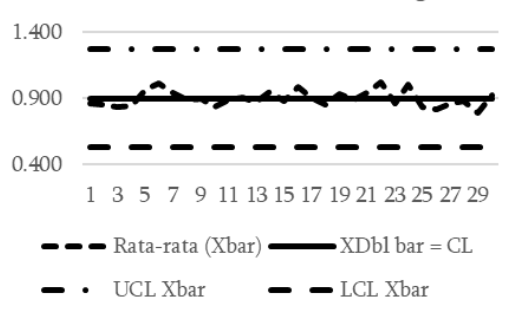

(f)
0.50

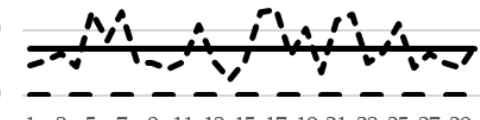

1357911131517192123252729

- - $\mathrm{R}(\mathrm{Rbar}) \quad$ Rbar $=\mathrm{CL}$

- - UCL Rchart - - LCL Rchart

Gambar 2. Grafik $X$-bar-R-Chart fruit strips Frutivez. (a) Ukuran varian mangga. (b) Ukuran varian pinepaya. (c) Ukuran varian pisang. (d) Ketebalan varian mangga. (e) Ketebalan varian pinepaya. (f) Ketebalan varian pisang 
Bahan buah yang dibeli pada waktu yang berbeda memiliki pengaruh yang sangat besar terhadap rasa akhir produk, namun perbedaan waktu tersebut juga memiliki pengaruh yang kecil terhadap bentuk akhir produk. Buah yang belum terlalu matang menyebabkan bentuk pure yang dihasilkan menjadi lebih cair sehingga menjadi sulit untuk dipotong karena cenderung menjadi terlalu tipis. Maka dari itu, secara tidak langung perbedaan waktu pembelian buah menjadi salah satu faktor yang mempengaruhi bentuk akhir produk. Faktor penyebab tersebut yang dirangkum dalam diagram sebab-akibat (fishbone diagram) pada

Gambar 3.

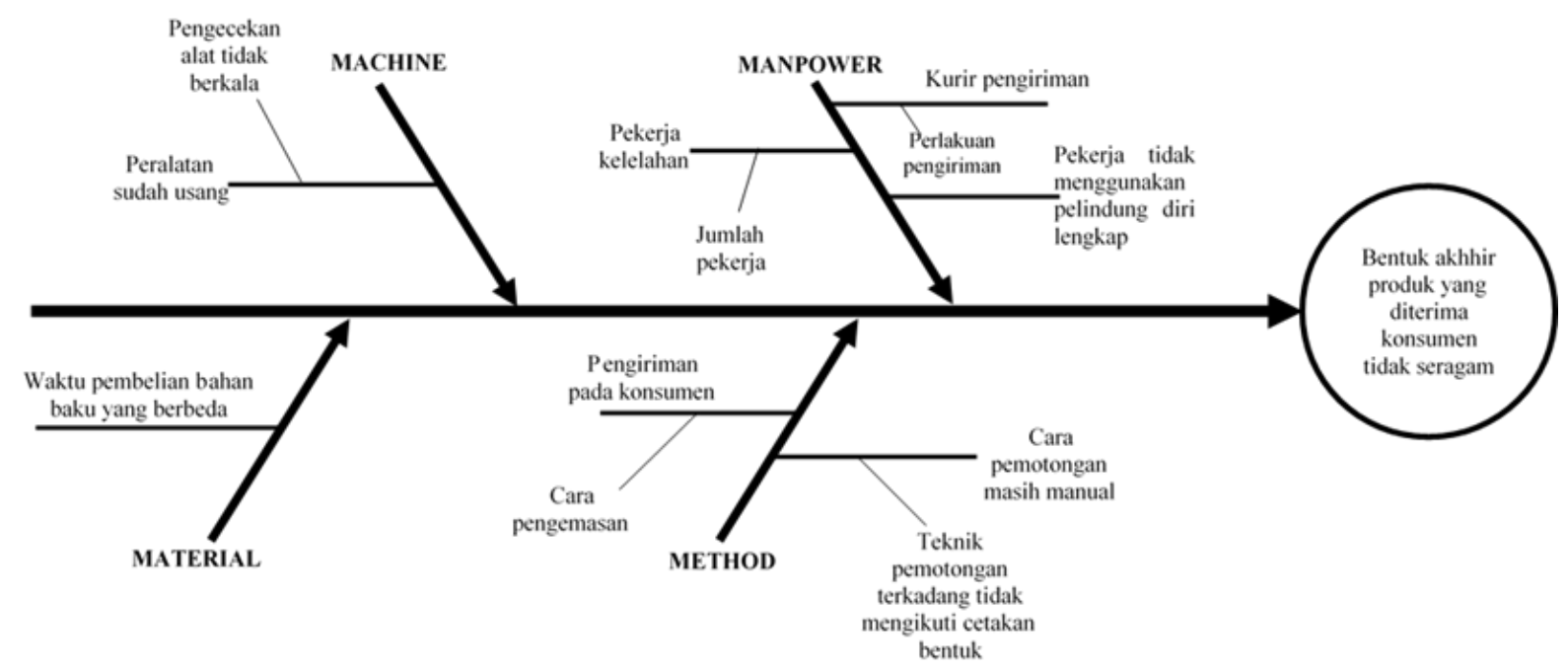

Gambar 3. Diagram sebab-akibat kecacatan bentuk produk Frutivez

\section{Solusi dan Evaluasi Perbaikan}

Untuk mengurangi bentuk fruit strips cacat yang diterima oleh konsumen, terdapat beberapa cara yang dapat dilakukan oleh perusahaan yaitu: (1) adanya opsi dus dan bubble wrap tambahan pada $e^{-}$ commerce dimana dus yang dimaksud adalah dus yang lebih tebal, (2) bonus dan rekreasi bersama (gathering) dapat diberikan oleh perusahaan guna meningkatkan solidaritas dan semangat kerja karyawan, (3) tray yang sudah tidak layak pakai (sudah tidak rata) sebaiknya diperbaiki atau dilakukan penggantian agar mempermudah proses produksi, serta (4) pembelian bahan baku sebaiknya dilakukan pada waktu yang bersamaan, namun buah perlu terlebih dahulu diolah menjadi pure dan disimpan pada lemari pendingin untuk mencegah terjadinya oksidasi.

Evaluasi dari solusi yang diberikan ini tidak dapat diamati lebih lanjut implementasinya oleh peneliti mengingat keterbatasaan waktu serta biaya yang dimiliki oleh peneliti untuk penelitian ini. Selain itu, solusi tersebut memerlukan pertimbangan lebih lanjut dari pihak perusahaaan sebelum diimplementasikan. Dengan demikian, untuk memvalidasi hasil penelitian ini seluruh solusi yang diberikan tersebut kemudian divalidasi terhadap pihak perusahaan untuk mengetahui persentase tingkat penerimaannya oleh pihak perusahaan. Penilaian kuesioner ini diisi oleh stakeholder yang memiliki kapasitas serta kepentingan yang sesuai, dimana pada penyebaran kuosioner ini yang dimaksud adalah internal PT. SABUSI yang terdiri dari 2 orang divisi produksi, 2 orang divisi marketing, dan 1 orang divisi administrasi.

Hasil dari penyebaran kuesioner tersebut didapatkan bahwa solusi (1), (2), (3), dan (4) persentase tingkat penerimaan oleh pihak perusahan secara berturut-turut adalah 87\%, 84\%, 81\%, dan $60 \%$, sehingga total persentase dari seluruh solusi yang diberikan adalah $78 \%$ atau setuju. Hasil kuosioner tersebut menunjukkan bahwa saran yang diberikan ke perusahaan berdasarkan hasil penelitian ini mengenai pengemasan, rekreasi karyawan, dan penggantian peralatan yang sudah usang disetujui oleh pihak perusahaan. Namun, waktu pembelian bahan baku yang diseragamkan menjadi satu minggu sekali perlu menjadi pertimbangan lebih lanjut bagi perusahaan. Hal tersebut karena masih diperlukannya penelitian dan pengujian lebih lanjut untuk formulasi dan memutuskan menerima ataupun menolak saran yang diberikan. 


\section{SIMPULAN}

Fruit strips yang diminati oleh mayoritas konsumen adalah fruit strips yang memiliki rasa manis asam, berukuran antara $30-40 \mathrm{~cm}^{2}$, memiliki ketebalan 0,05 $\mathrm{mm}$, berbentuk persegi panjang, dan memiliki tekstur permukaan yang agak bertekstur. Kecacatan yang sering dijumpai pada produk fruit strips Frutivez adalah bentuk akhir produk yang patah saat diterima oleh konsumen. Kecacatan tersebut disebabkan oleh kurir yang tidak berhatihati saat mengirimkan pesanan konsumen, cara pengemasan yang kurang aman, pekerja merasa jenuh saat melakukan produksi, serta peralatan (tray) yang sudah usang. Solusi yang diberikan adalah penambahan opsi dus dan bubble wrap tambahan pada e-commerce, melakukan gathering karyawan secara berkala, dan penggantian peralatan yang sudah rusak dan pemeliharaan untuk seluruh mesin dan peralatan. Diperlukannya penelitian lanjutan guna mengevaluasi hasil solusi yang telah diimplementasi oleh perusahaan.

\section{UCAPAN TERIMA KASIH}

Terima kasih disampaikan kepada PT. SABUSI yang telah memfasilitasi pelaksanaan penelitian serta kepada semua pihak yang telah membantu di dalam pelaksanaan penelitian.

\section{DAFTAR PUSTAKA}

Amanah, D. 2010. Pengaruh Harga dan kualitas produk terhadap kepuasan pada konsumen Majesty Bakery dan Cake Shop Cabang H.M. Yamin Medan. Jurnal Manajemen Strategi dan Aplikasi Bisnis. 2(1): 71-87.

Badan Pusat Statistik. 2018. Statistik Tanaman Buahbuahan dan Sayuran Tahunan Indonesia.

Elan, U, dan Kusmindah, DH. 2016. Pengaruh Total quality management terhadap kepuasan pelanggan pada Derpartemen BUBI (Bidang Usaha Barang Industri) PT. Varia Usaha di Gresik. Gema Ekonomi (Jurnal Fakultas Ekonomi). 5(2): 178-1825.

Elmas, MSH. 2017. Pengendalian kualitas dengan menggunakan metode statistical quality control untuk meminimumkan produk gagal pada Toko Roti Barokah Bakery. Jurnal Penelitian Ilmu Ekonomi WIGA. 7: 15-22.

Enie, AB, dan L Nami 1992. Penelitian pembuatan makanan ringan asal buah-buahan tropis I: Pengaruh sulfit dan lama penyimpanan terhadap mutu fruit leathers. Warta IHP. 9(12): $18-21$.

Hamidah, S. 2015. Sayuran dan Buah Serta Manfaatnya Bagi Kesehatan. Tersedia online pada

http://staffnew.uny.ac.id/upload/130799888/p enelitian/sayuran.pdf. Diakses Agustus 2021.

Heizer, J, dan B Render. 2011. Manajemen Operasi. Salemba Empat. Jakarta.

Mast, JD, and A Trip. 2005. Gauge R\&R studies for destructive measurements. Journal of Quality Technology. 37(1): 40-49.

Nastiti, H. 2014. Analisis pengendalian kualitas produk dengan metode statistical quality control (Studi kasus: pada PT “ X” Depok). JP FEB Unsoed. 4(1): 414-422.

Oakland, JS. 2008. Statistical Process Control. Butterworth-Heinemann. Oxford.

Ramadhany, FF, dan Supriono. 2015. Analisis Penerapan sistem manajemen mutu ISO 9001 : 2015 dalam menunjang pemasaran (Studi pada PT Tritama Bina Karya Malang). Jurnal Fakultas Ilmu Administrasi Universitas Brawijaya. 53(1): 31-38.

Ratnadi, dan E Suprianto. 2016. Pengendalian kualitas produksi menggunakan alat bantu statistik (Seven Tools) dalam upaya menekan tingkat kerusakan produk. INDEPT. 6(2): 1018.

Rusydah, M, dan YT Utomo. 2019. Analisis manajemen pengendalian mutu produksi pada Bakpiapia Djogja tahun 2016 berdasar perencanaan standar produksi. AT-TAUZI': Jurnal Ekonomi Islam. 18(1): 47-72.

Sari, NKR, dan NK Purnawati. 2018. Analisis pengendalian kualitas proses produksi pie susu pada perusahaan pie susu Barong di Kota Denpasar. E-Jurnal Manajemen Unud. 7(3): 1566-1594.

Winarsih, S. 2017. Kebijakan dan implementasi manajemen pendidikan tinggi dalam meningkatkan mutu pendidikan. Cendekia. 15(1): 52-66.

Yilmaz, FM, S Yuksekkaya, H Vardin, and M Karaaslan. 2017. The effects of drying conditions on moisture transfer and quality of pomegranate fruit leather. Journal of the Saudi Society of Agricultural Sciences. 143: 33-40. 